\title{
PATHOGENESIS OF PROSTHESIS-RELATED INFECTION
}

\author{
Jiří Gallo ${ }^{a^{*}}$, Milan Kolář ${ }^{\circ}$, Radek Novotnýc, Petra Řihákovád, Vlasta Tichád
}

\author{
a Department of Orthopaedic Surgery, Faculty of Medicine, Palacký University, 77515 Olomouc, Czech Republic \\ ${ }^{b}$ Department of Microbiology, Faculty of Medicine, Palacky University \\ c Department of Microscopy Methods, Faculty of Medicine, Palacký University \\ d Department of Pathology, Faculty of Medicine, Palacký University
}

Received: May 3, 2003

Key words: Prosthesis-related infections / Complication / Joint arthroplasty / Bacterial biofilm / Glycocalyx

In spite of its incidence decreasing to $1 \%$ nowadays, prosthesis-related infection remains a research, diagnostic, therapeutic and cost-related problem. It can be defined as a presence of bacteria in the artificial joint space, which is significantly associated with evident laboratory and/or tissue markers, and clinical signs of running infection. We believe that the more precise understanding of pathogenesis, the more effective preventative and therapeutic measures, and the lower infection rate. The implants are colonized by airborne, skin-, and/ or surgeon-related bacteria during surgery despite being operated in closely respected operating regime. Some prosthetic characteristics are advantageous and may play important roles in the process of bacterial adherence. After successful attachment on the biomaterial surface bacteria multiply and physiologically transform into a "biofilm" community, making them much more resistant to antibiotic therapy and host immunity. Bacterial resistance is a complex phenomenon influenced by intrinsic and extrinsic factors, including the cell configuration in the biofilm community. So the cure of periprosthetic sepsis without removing of all foreign bodies and necrotic bone fragments is often ineffective. Acute hematogenous sepsis is suggestive of a distortion of a previously aseptic joint space by invasion of bacteria through the vessels.

\section{INTRODUCTION}

Total hip or knee arthroplasties belong to the most common orthopaedic procedures. They are routine, effective, and successful. However, complications can occur and frustrate both the surgeon and his or her patient. Deep infection is considered as one of the most serious complications. It belongs to the large group of infections associated with indwelling medical devices. It can be defined as the presence of bacteria in an artificial joint space, which is significantly associated with evident laboratory and/or tissue markers, and clinical signs of running infection.

According to the Swedish registry (1979-1998) there were $7.2 \%$ hip arthroplasties revised due to a deep sepsis. ${ }^{46}$ The revision rate of total hip arthroplasty due to sepsis was $7 \%$ in Finland in 1999 and $10.5 \%$ in Denmark between 1995 and 1998. ${ }^{44,58}$ In general, current rates of deep infection are estimated around $1 \%$ and between $1 \%$ and $2 \%$ for primary hip and knee arthroplasties, respectively. ${ }^{20,29,41,63,65}$ The incidence of infection following a revision hip arthroplasty has been reported to range between 2 and $6 \% .^{20,29}$

Some investigators have suggested that the real number of deep sepsis is higher. ${ }^{51,75}$ For instance, Pilnáček and Bébrová strongly supported this opinion in the Czech Republic having found 20 positive intra- operative cultures in the group of 29 preoperatively "aseptic" cases. ${ }^{57}$ The endeavour of this "research party" has culminated with the idea that aseptic failure of artificial joints is not as common as literature may report. However, we cannot be definitely sure that positive intraoperative cultures obtained by sophisticated techniques from prosthetic surfaces are relevant to prosthesis-related infection because of the lack of the tissue (Fig. 1) or systemic response..$^{29,50,61,71}$ On the other side it is evident that colonization of prosthetic surfaces is a key prerequisite for all acceptable natural histories of prosthesis-related infection.

Coventry distinguished three basic clinical types of periprosthetic infection: acute postoperative, late chronic, and acute hematogenous. ${ }^{13}$ The acute postoperative type develops within three months after the surgery. With the chronic type, delayed sepsis occurs 3 to 24 months after the surgery. The last type (AHI) can be expressed at any time postoperatively, but it is necessary to demonstrate causal and chronological relations to running infection at any site in the host body. Tsukayama et al. defined the fourth type of periprosthetic infection, the so-called positive intraoperative culture referring to asymptomatic bacterial colonization of prosthetic surfaces. $^{74}$

Schmalzried et al. claimed that the majority of deep hip arthroplasty infections were nonsurgical. ${ }^{69}$ We and 


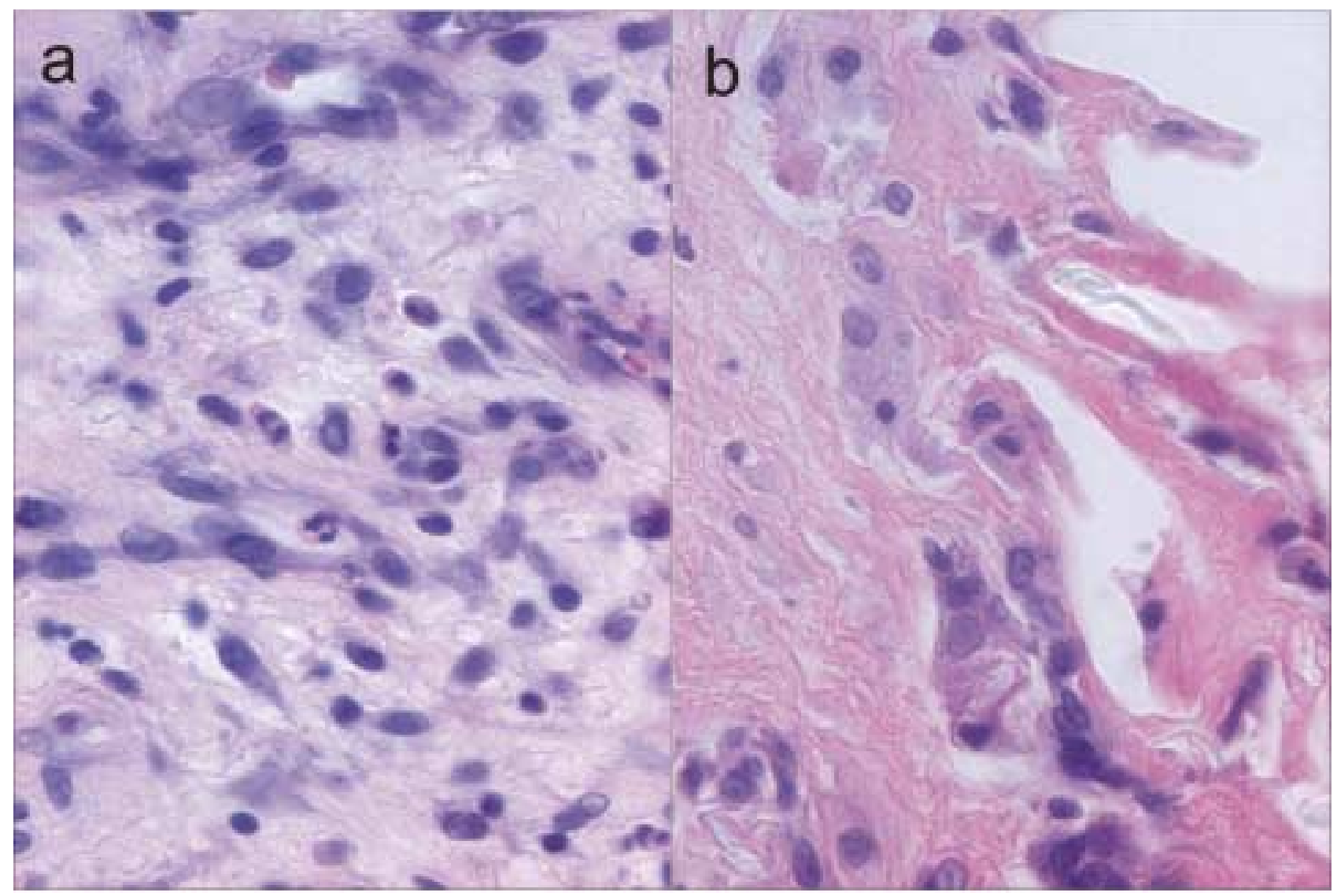

Fig. 1. a - a case of septic failure after TKA. Non-specific inflammatory tissue is present with budding capillaries, PMNs, lymphocytes and fibroblasts. HE, 400×.

$\mathrm{b}-\mathrm{a}$ case of aseptic failure after THA. The specimen demonstrates a foreign body reaction around suspicious polyethylene particles (empty spaces). Multinucleated large cells and mononuclear histiocytes with fumous slightly basophile cytoplasma are visible. HE, 400×.

some other clinicians do not fully agree with this opinion. ${ }^{7,71}$ Actually, one-third of all septic failures due to hematogenous spread seems to be a more realistic estimate.

Successful treatment necessitates prompt and good diagnosis, preferably based on a microbial analysis, and adequate knowledge on the patient profile. At present, both of them are subjects of controversies. McPherson et al. developed a staging scheme for prosthesis-related infection consisting of three main variables: infection type, medical and immune status of a host, and local status of the afflicted extremity ${ }^{47}$ That was done with hope that a more appropriate approach could be chosen out of several therapeutic options, i.e. chronic antibiotic suppression, debridement with retention of prosthesis, reimplantation of new prosthesis, arthrodesis, amputation. It is believed that each of the clinical types of periprosthetic infections has its therapeutic and prognostic consequences. ${ }^{15,16,27,30,74}$

According to the literature, the failure rate of twostage revision knee arthroplasty is ranging between $0 \%$ and $23 \%,{ }^{48}$ except the study by Rand et al. ${ }^{62}$ who reported a failure rate of $44 \%$ (4/9). A direct exchange of infected hip arthroplasty (one-stage reimplantation) may be successful in almost $83 \%$ of cases, ${ }^{29,}{ }^{37}$ whilst with delayed reimplantation the rate of success may reach $94 \% .29,52,82,83$

The management of infected arthroplasties has serious economic implications. Eg. in the United States, the annual cost to treat 3,500 to 4,000 cases equalled 150 to 200 million USD. ${ }^{65}$ Sculco also argued that "early recognition of infection and aggressive treatment by implant removal will reduce patient risk and health care expense". ${ }^{65}$

The most frequent prosthesis-related pathogens are coagulase-negative staphylococci and Staphylococcus aureus,${ }^{15}$ which strongly implicates the intraoperative contamination scenario. From the pathogenetic point of view it is possible to convert Coventry-Tsukayama's classification into two types only, namely the infection associated with intraoperative colonization of prosthesis (surgical type), and a rarer form of postoperative hematogenous colonization of the joint space (Fig. 2). Having achieved firm adherence, the founder bacteria form a biofilm colony by multiplying with specific space organizing, and changing their physiology. The biofilm, as a special form of bacterial life, is much more resistant than the planktonic one, in practice being incurable without surgical removal. Consequently, it may be alleged that more precise understanding of prosthe- 
a

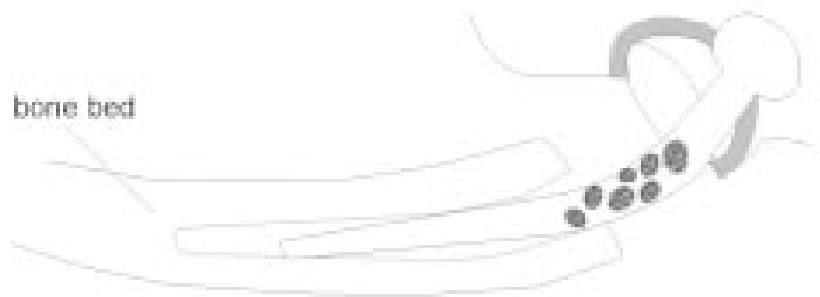

b

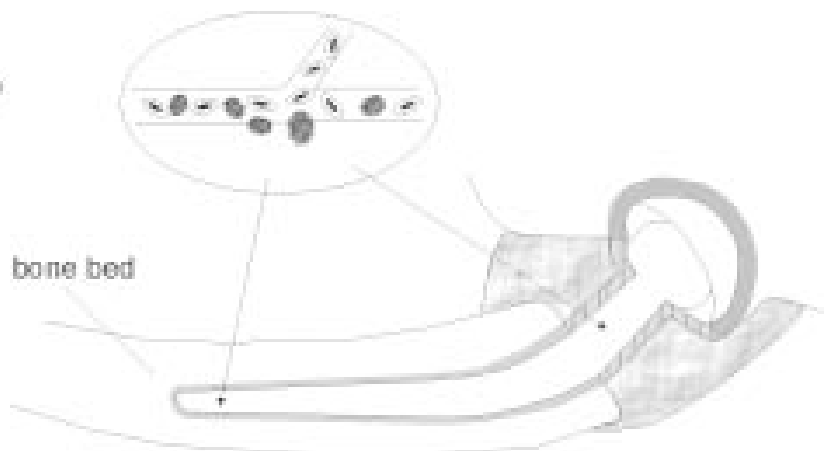

Fig. 2. Two basic pathogenetic concepts of prosthesis-related infection.

a - surgical-related periprosthetic infection. Bacteria colonizing prosthetic or bone surfaces during surgery. The whole process is influenced by quantitative and qualitative parameters of host and bacterial organisms.

$\mathrm{b}$ - hematogenous periprosthetic infection. Bacteria invading into the sterile encapsulated joint space through vessels (bacteremia).

sis-related infection pathogenesis could improve preventative and therapeutic measures. The aim of the present review is to make an outlook on the up-to date knowledge on this issue.

\section{CHARACTERISTICS OF COMMON "ORTHOPAEDIC" BACTERIA}

There are only several bacterial species that play a role in prosthesis-related infections. A majority of them is caused by Staphylococcus epidermidis and Staphylococcus aureus (Table 1). Moreover, vancomycinresistant enterococcus has recently become one of the most serious pathogens..$^{33,68}$

Airborne bacteria present in operating rooms are predominantly gram-positive microorganisms, and most of them are derived from the skin, hair, and nose or oral cavity of patients and operating room staff. ${ }^{28,35,64}$ The skin at the operative site can be a source of bacteria in spite of numerous contemporary antiseptic procedures.
The wound edges can be recolonized by bacteria within 30-180 minutes after the preparing of a patient. ${ }^{38,64}$ In addition, the modern adhesive draping may damage a thin superficial layer of the skin, revealing deeper, more resistant, bacteria.

Staphylococcus aureus belongs to the most virulent bacteria. ${ }^{11}$ It is a common nosocomial pathogen which can produce much more extracellular proteins than coagulase-negative staphylococci. ${ }^{43,79}$ Hence, the enzymes and toxins are regarded as its main factor of virulence. ${ }^{39,79}$

Coagulase-negative staphylococci include at least fifteen different species, ${ }^{2}$ and some of them are now reckoned among leading pathogens causing periprosthetic infections (Table 1). They form an extracellular matrix named glycocalyx which is a fundamental of their survival strategy.

It is well-known that prosthetic surfaces can act as a unique microbial substratum. The presence of polyethylene seems to be much more attractive for Staphylococcus epidermidis (Fig. 3) compared to Staphylococcus aureus, while prosthetic metals are more suited for Sta-

Table 1. A list of contributors supporting a hypothesis on the main role of staphylococci in prosthesis-related infections.

\begin{tabular}{|c|c|c|c|c|c|}
\hline Authors & Site of infection & $\begin{array}{c}\text { Number of cases/ } \\
\text { pathogens }\end{array}$ & $\begin{array}{c}\text { Gram-positive } \\
\text { organisms }\end{array}$ & STAU & $\begin{array}{c}\text { Coagulase- } \\
\text { negative STA }\end{array}$ \\
\hline${\text { Banit et } a l^{4}}^{4}$ & THA,TKA,SA & $21 / 23$ & $83 \%$ & $43 \%$ & $26 \%$ \\
\hline Backe et $a l^{3}{ }^{3}$ & TKA & $12 / 11$ & $82 \%$ & $27 \%$ & $27 \%$ \\
\hline Gambhir et al. ${ }^{18}$ & THA & $301 / ?$ & $87 \%$ & $14 \%$ & $55 \%$ \\
\hline Garvin et al. $^{19}$ & THA, TKA & $76 / 97$ & $76 \%$ & $19 \%$ & $37 \%$ \\
\hline Goldman et al. ${ }^{21}$ & TKA & $64 / 67$ & $72 \%$ & $22 \%$ & $31 \%$ \\
\hline Hanssen, Osmon $^{30}$ & THA & $37 / 47$ & $83 \%$ & $28 \%$ & $32 \%$ \\
\hline Holzer et al..$^{34}$ & Megaprostheses & $18 / 16$ & $94 \%$ & $25 \%$ & $56 \%$ \\
\hline Segawa et al. ${ }^{66}$ & TKA & $81 / 88$ & $95 \%$ & \multicolumn{2}{|r|}{$73 \%$} \\
\hline Tsukayama et al. ${ }^{74}$ & THA & $106 / 147$ & $74 \%$ & $22 \%$ & $38 \%$ \\
\hline Ure et al. $^{76}$ & THA & $20 / 20$ & $100 \%$ & $25 \%$ & $45 \%$ \\
\hline Whiteside $^{80}$ & TKA & $33 / 33$ & $85 \%$ & $15 \%$ & $33 \%$ \\
\hline Younger et al. ${ }^{82}$ & THA & $30 / 29$ & $83 \%$ & $21 \%$ & $45 \%$ \\
\hline
\end{tabular}



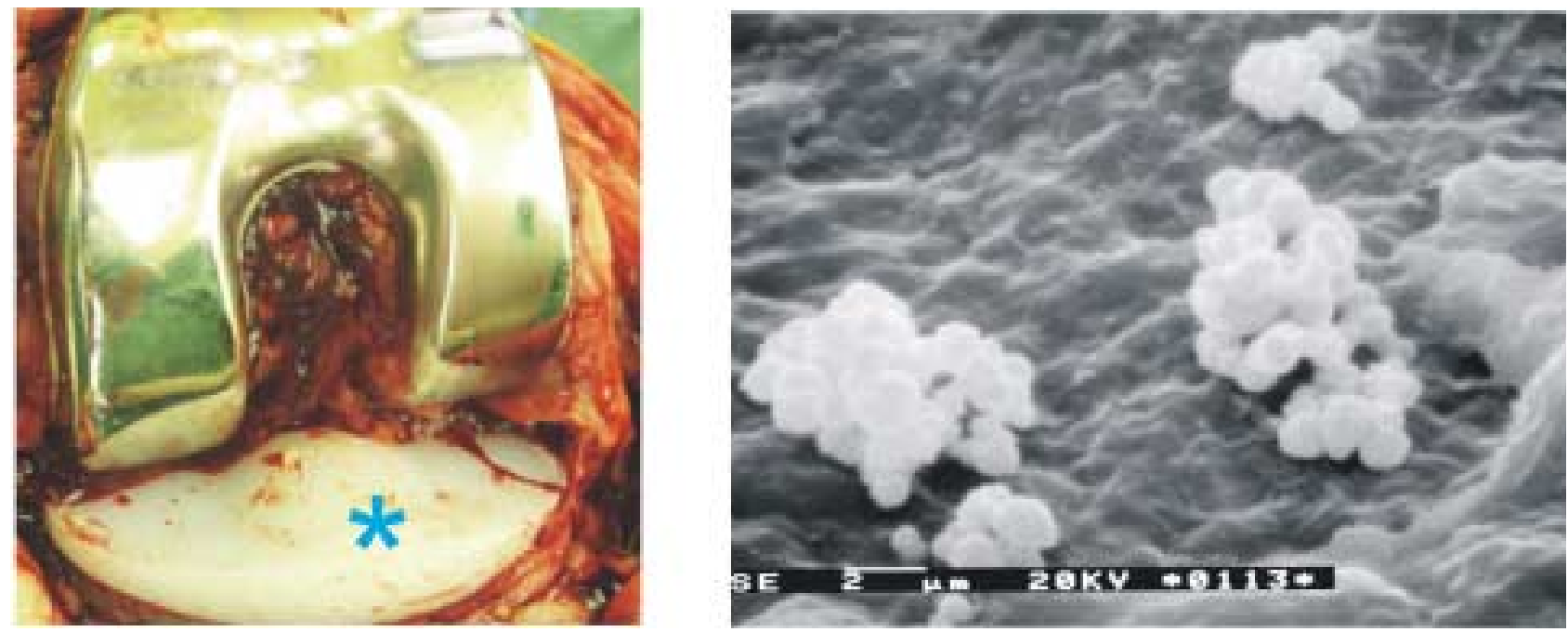

Fig. 3. a - intraoperative view of a revised TKA with whitish coating (asterisk) on the polyethylene surface.

$\mathrm{b}$ - Staphylococcus epidermidis bacterial colonies on the polyethylene surface under scanning electron microscope (SEM).

phylococcus aureus. ${ }^{23,25}$ Corrosion products from metal surfaces can stabilize and strengthen their biofilm construction. ${ }^{14,23,24}$ In addition, polymethylmethacrylate increases the likelihood of infection by a combination of favourable surface characteristics and a negative influence on chemotaxis, phagocytosis, and the biological status of its surroundings. ${ }^{55,56}$ It was also suggested that Staphylococcus epidermidis might metabolize some esters released from bone cement. ${ }^{23}$

The recent literature data estimate that almost $90 \%$ of staphylococci are penicillin resistant, and the resistance to oxacillin is also increasing. ${ }^{2,59}$ Unfortunately, oxacillin resistance involves cross-resistance to all other $\beta$-lactam antibiotics. ${ }^{2}$ Also, there are rare, but very serious infections caused by streptococci (mainly group $\mathrm{G}$ ) and Gram-negative pathogens (Pseudomonas aeruginosa, Proteus mirabilis, etc.). Furthemore, the role of anaerobic bacteria has been confirmed by several studies (e.g. Propionibacterium acnes and some strain of peptostreptococci), ${ }^{16,19,57,74}$ and symbiotic bacterial species also cooperate symbiotically in biofilm colonies causing a polymicrobial prosthesis-related infection.

\section{BACTERIAL ADHESION}

It is believed that the key factor for the prosthesisrelated infection development is bacterial adherence on the artificial joint surfaces. The chance for successful bacterial colonisation of the joint space is influenced by the prosthetic surface characteristics, occurrence of dead bone fragments, and it is also dependent on host factors (immune, non-immune). In addition, an important role is played by the number of bacteria and their genetic characteristics. ${ }^{14,25,26}$

Implants are covered with blood fractions (proteins, plasma macromolecules, erythrocytes, thrombocytes, etc.) immediately after their insertion, referred to as a conditioning film. ${ }^{77}$ Now it is hypothesized that constituent bacteria are able to adhere on the conditioning film, uncovered prostheses, or fragments of a dead bone by help of a wide range of physical and chemical interactions (Fig. 4). These include van der Waals's forces, acid-base, electrostatic and hydrophobic interactions, protein bindings, etc. ${ }^{14,53,54,78}$ The surface characteristics of the biomaterial also seem to be of importance, including hydrophilicity, roughness, and surface charge. The more hydrophilic and rougher, the better for bacterial adhesion. ${ }^{10,73}$ There are at least two phases of bacterial attachment to distinguish: reversible (non-specific) and irreversible (specific). The reversible adhesion relies on the non specific physical and chemical characteristics of the bacteria, as well as on the biomaterial and surrounding joint fluid. The irreversible attachment is mediated through more specific structures, for example adhesin receptors expressed on the bacteria surfaces (Fig. 4). They guarantee strong fixation of the bacteria on the prosthetic surfaces covered with a conditioning film. ${ }^{32,49,78}$ Götz and Peters suggested that the adherence of Staphylococcus aureus is done mainly via adhesin structures bound on host protein-coated surfaces, while the attachement of Staphylococcus epidermidis depends largely on hydrophobic interactions. ${ }^{22}$

\section{PROSTHETIC-RELATED BIOFILM DEVELOPMENT}

Gristina et al. proposed an elegant pathogenetic metaphor for the situation occurring shortly after the insertion of implants: "the race for the surface". ${ }^{25}$ According to this concept, the adhesion of bacteria and the integration of biomaterials are similar processes. Therefore, the final result (i.e. host coverage of the prosthetic surface or succesful bacterial adhesion) depends primarily on the velocity and configuration of these processes. 


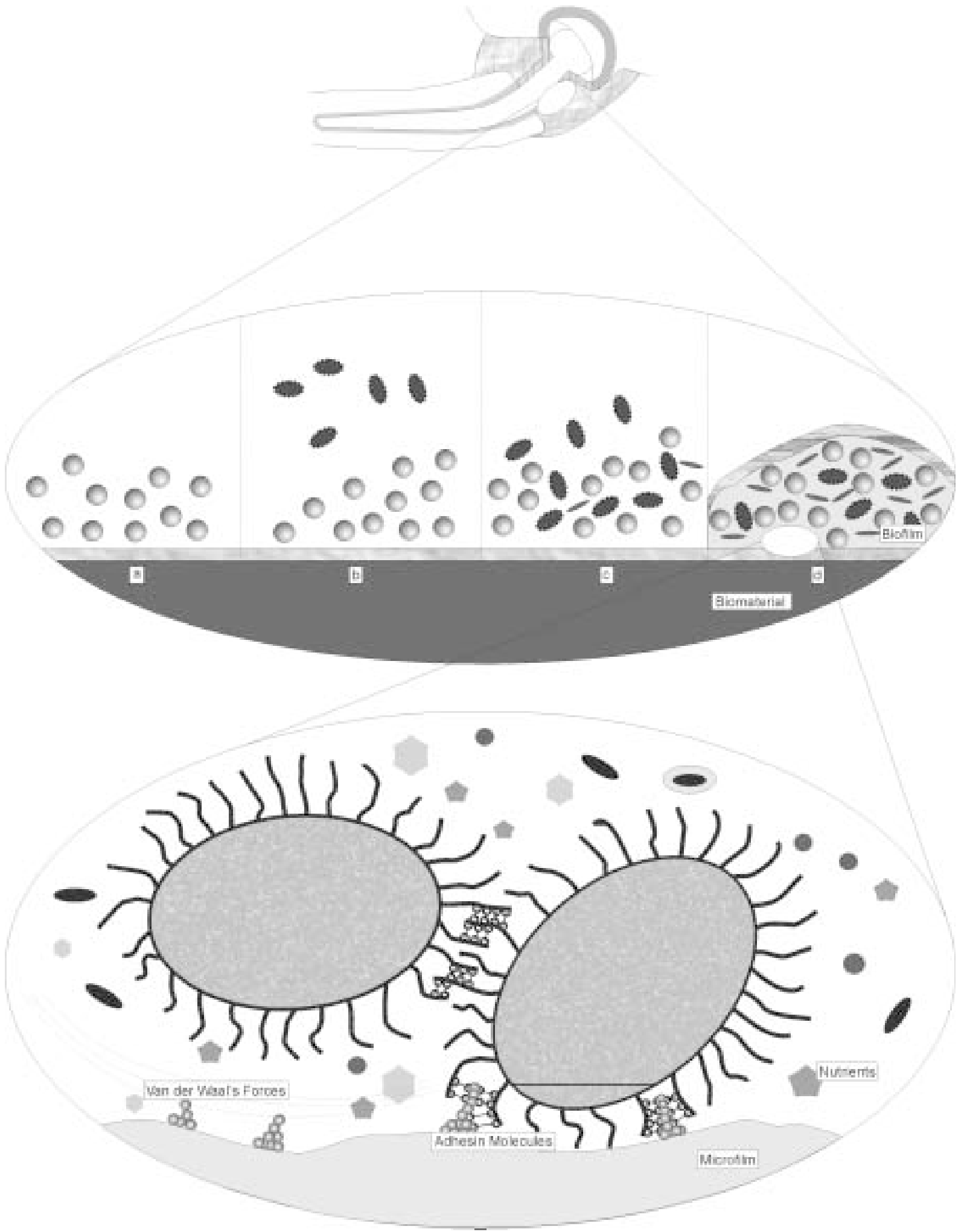

Fig. 4. Bacterial biofilm development:

a - immediately after prosthesis insertion the surface is covered with host macromolecules or cells (conditioning film).

b - conditioning film or pure prosthetic surface is colonized with bacteria of airborne-, surgical-, skin- or hematogenous origin.

c - non-specific bacterial adhesion realized by van der Waals's forces, acid-base, electrostatic and other interactions.

$\mathrm{d}$ - irreversible locking to biomaterial done through multiple specific binding (mainly adhesin molecules). Mature bacterial biofilm is encapsulated by host fibrous tissue. ${ }^{14,24,25,77}$ 

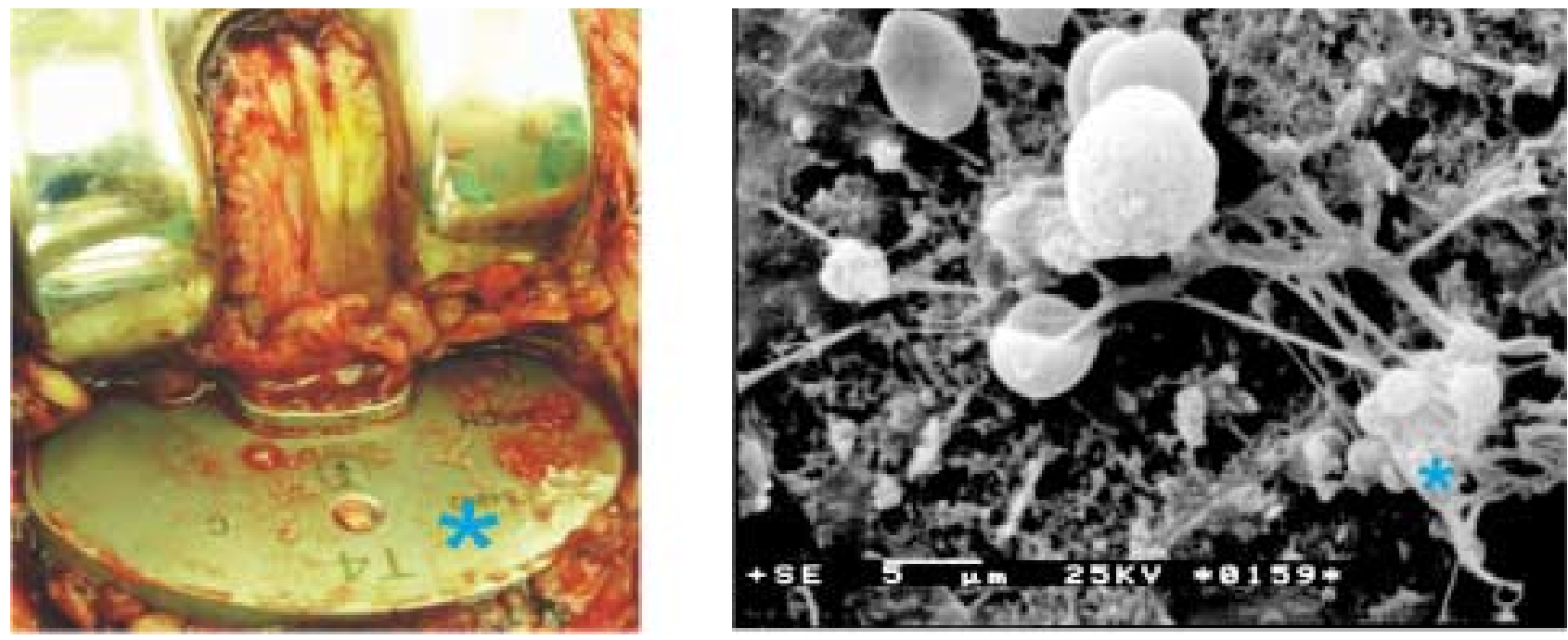

Fig. 5. a - intraoperative view of a revised TKA after polyethylene insert retrieval (same case as in Fig. 3). Jelly-like structures (asterisk) as observed on the tibial component surface.

$\mathrm{b}$ - blood elements, fibrin and a suspicious group of bacteria (asterisk) on the metal surface under SEM.

If the winner are bacteria, they can display their survival strategy. More virulent pathogens expand through their ellaboration of extracellular proteins (invasins) ${ }^{79}$ which is in contrast to less virulent pathogens producing large amounts of extracellular slime to embed and protect bacterial cells. The glycocalyx can also stimulate monocytes to secrete $\mathrm{PGE}_{2}$ which inhibits proliferation of T-lymphocytes. ${ }^{72}$ The composition of slime remains controversial; however, it is suggested to be primarily a complex polysaccharide substance. ${ }^{45}$ One may assume that the formation of this structure, including fixation to the biomaterial, may be a time-, energy- and materialconsuming process.

The biofilm consists of bacterial as well as host parts that are created by fibrin, polymorphonuclear neutrophils, erythrocytes, histiocytes, fibroblasts and many others constituents (Fig. 5). ${ }^{9}$ A fibrous capsule on the outer surface of the biofilm can be considered as the interface between host and bacterial organisms. ${ }^{9}$

Having observed the biofilm, Costerton et al. ${ }^{12}$ introduced a metaphor "it looks like the rocks in Alpine streams" to describe it. According to Dunne ${ }^{14}$ the mature biofilm resembles an underwater coral reef with a large number of channels and cavities to allow the exchange of nutrients, waste, and signals. The bacteria living under optimal conditions (nutrient, waste, gas, space limitations) slow their growing rate, activate several survival mechanisms or separate from the colony. ${ }^{14,24}$ Under certain conditions a symbiotic relationship between more than one bacterial species may be advantageous for the development of biofilm colonies.

\section{POSSIBLE SCENARIOS}

\section{OF PROSTHESIS-RELATED INFECTION}

The basic prerequisite for the development of prosthesis-related infection is successful bacterial colonisa- tion of prosthetic and/or bone surfaces around the artificial joint space. Another important aspect is the host body status, particularly the immune system and local tissues. Impairment of the immunity due to prosthesisrelated $^{23,25,55,56}$ and/or patient-related factors (advanced age, chronic inflammatory diseases, diabetes mellitus, malnutrition, immunosupressive drugs, chronic renal insufficiency, etc. $)^{27,47}$ play an important role in pathogenesis and onset of periprosthetic infections. The number of "slightly" immunocompromised persons may be increasing, among others as a result of a wide usage of broad-spectrum antibiotics.

Once the bacteria have succesfully reached and adhered on the artificial joint surfaces they begin to display their programmes for self-preservation (transformation, communication, invasin production, biofilm construction, etc.). They are perceived as a foreign organism in the host body which triggers an immune response with inflammation. The character of this response can be modified by a chronically immunoincompetent inflammatory zone surrounding artificial joints (e.g. exhausted macrophages). ${ }^{23}$ Inside of this effective joint space there is a huge number of prosthetic debris binding (exhausting) macrophages and other connective tissue cells in the self-perpetuating particle disease. ${ }^{17,31,81}$ Several authors have found that adherent endotoxin is important for a particle-induced osteolysis in vitro. ${ }^{5,8,36}$ Regardless of the mechanism of periprosthetic osteolysis it is attractive to believe that osteolysis may maintain immunoincompetency, facilitate expansion of the biofilm community, and/or development of hematogenous infection.

One can speculate at least four scenarios on the natural history of periprosthetic infection:

1. Prosthesis-related infection associated with intraoperative inoculation of the joint space by virulent microorganisms causes rapid and early inflammation. This form of infection is influenced mainly by factors of 
pathogen virulence, whilst the role of host immunity seems to be secondary. Clinically there are clear local signs of inflammation, often accompanied by several systemic symptoms. Some strains of Staphylococcus aureus and other pathogens can produce aggressive extracellular proteins (toxic-shock syndrome toxin, etc.) that are able to overcome local barriers and lead to global sepsis.

2. Prosthesis-related infection associated with strong intraoperative or early postoperative contamination of less virulent organisms in a competent host can be occult for some time. The onset of infection is usually manifested within two years after the surgery. The longer the time to the onset, the lesser the virulence and/ or the better host immunity. The "balance" between biofilm community and the surrounding host tissue can be lost gradually under the influence of functioning prosthesis, local metabolic conditions, the tendency of bacteria to expand, or dysfunction of the bone bed. Although it remains unclear how long the occult bacterial infection can be present without provocation of the host immunity, it still seems that several years can be expected. ${ }^{51,75}$ Another interesting question may arise: What is the cause of sudden biofilm recognition by the host immunity? It could be due to pathogen-related conflicts (space, nutrient or waste limitations) leading to the biofilm degradation. Further explanation can be based on synergy between bacterial activity and running particle disease. Biofilm colonies can expand simultaneously with the expansion of the joint space associated with particle disease (chronically immunoincompetent environment, necrotic bone and soft tissues, etc.). On the other hand, it is believed that the host reaction in connection with antibiotic prophylaxis can eliminate the majority of the less virulent contamination.

3. Prosthesis-related infection associated with small intraoperative contamination of less virulent microorganisms depends on the host status. The healthy host body in concert with antibiotics is capable to eradicate these microorganisms easily as this is its routine experience, whilst successful colonization is in progress in weakened patients. The more unstable the host immunity, the quicker the clinical failure development. After a "steady state" period mainly controlled by microbial characteristics (i.e. recuperation, multiplication, growing, etc.) a phase of increasing symptoms may set out including early loosening of implants.

4. The hematogenous prosthesis-related infection is based on two facts: Each of us can have bacteremia under normal situations, ${ }^{40,42}$ and microorganisms in the bloodstream are able to leak in the artificial joint space. ${ }^{6,70}$ Therefore, there may be some risk for all the patients with artificial joint replacement to develop hematogenous deep periprosthetic sepsis. ${ }^{1}$ The diagnosis of hematogenous prosthesis-related infection must be based on the pathogen identity and time period, which can be often difficult to establish. On the other hand, a finding of specific oral cavity flora in the hip or knee is very suspicious for hematogenous seeding. It should be emphasized that the concept of "race for the surface" cannot explain adequately hematogenous bacterial seeding of the previously well functioning prosthesis. It is supposed that the artificial joint space is seeded with significant bacteremia of dental, ${ }^{40,42}$ urogenital, gastrointestinal or other origins. ${ }^{69}$ Today, there is also increasing knowledge on vascular catheter-related infections $s^{60}$ that are now frequently encountered. According to Sheretz, catheters may become colonized by skin microflora within 8 days in 70 to $90 \%$ of cases. ${ }^{67}$

\section{CLINICAL CONCLUSIONS}

There are three crucial consequences resulting from this review:

1. Preventative - it is impossible to eliminate a risk of prosthesis-related infections, but the preventative measures are strongly worth the effort.

2. Diagnostic - it is difficult to detect locally adherent bacteria by routine techniques focused mainly on planktonic bacteria.

3. Therapeutic - it is not possible to cure deep infection without implant removal and radical debridement. Even if this is done, a danger of the septic failure persists for a longer period of time.

Infection following total joint arthroplasty remains a serious complication. Virulent pathogens cause an acute form of infection with a consistent clinical picture and laboratory findings. However, the majority of periprosthetic infections are due to human skin saprophytes of low virulence that are able to provoke only minimal or no symptoms for some time, but they can be very resistant to both the host immunity and antibiotics under the biofilm "umbrella". Finally, the cultures obtained from different articular sites can be negative in spite of evidently running infection. The incorrect diagnosis may lead to inappropriate surgical procedures associated with a high risk of failure.
A list of abbreviations used:
$\mathrm{PGE}_{2}$ - Prostaglandin $\mathrm{E}_{2}$
PMNs - polymorphonuclear leukocytes
SA - shoulder arthroplasty
STA - staphylococci
STAU - Staphylococcus aureus
THA - total hip arthroplasty
TKA - total knee arthroplasty

\section{ACKNOWLEDGEMENTS}

The authors would like to thank Ms. J. Potomkova for editorial work. The work is supported by the Grant Agency IGA (grant No. NM7680). 


\section{REFERENCES}

1. Ainscow DAP, Denham RA. (1984) The risk of hematogenous infection in total joint replacements. J Bone Jt Surg 66-B, 580-2.

2. Archer GL. (2000) Staphylococcus epidermidis and other coagulase-negative staphylococci. In: Mandell, Douglas and Bennett's principles and practice of infectious diseases. Eds. Mandell GL, Bennett JE, Dolin R. 5th ed. Churchill Livingstone, 2092-2100.

3. Backe HA, Wolff DA, Windsor RE. (1996) Total knee replacement infection after 2-stage reimplantation. Clin Orthop 331, $125-31$.

4. Banit DM, Kaufer H, Hartford JM. (2002) Intraoperative frozen section analysis in revision total joint arthroplasty. Clin Orthop 401, 230-8.

5. Bi Y, Seabold JM, Kaar SG, Ragab AA, Goldberg VM, Anderson JM, Greenfield EM. (2001) Adherent endotoxin on orthopedic wear particles stimulates cytokine production and osteoclast differentiation. J Bone Miner Res 16, 2082-91.

6. Blomgren G, Lindgren U. (1980) Postoperative infections resulting from bacteriemia: an experimental study in rabbits. Acta Orthop Scand 51, 761-5.

7. Brause BD. (1998) Sepsis: The rational use of antibiotics. In: The adult hip. Eds. Callaghan JJ, Rosenberg AA, Rubash HE. Philadelphia, Lippincott-Raven, p. 1343.

8. Brooks RA, Wimhurst JA, Rushton N. (2002) Endotoxin contamination of particles produces misleading inflammatory cytokine responses from macrophage in vitro. J Bone Jt Surg 84-B, 295-9.

9. Buret A, Ward KH, Olson ME, Costerton JW. (1991) An in vivo model to study the pathobiology of infectious biofilms on biomaterial surfaces. J Biomed Mater Res 25, 865-74.

10. Busscher HJ, Sjollema J, Van der Mei HC. (1990) Relative importance of surface-free energy as a measure of hydrophobicity in bacterial adhesion to solid surfaces. In: Microbial cell surface hydrophobicity. Eds. Doyle RJ, Rosenberg M. American Society for Microbiology. Washington. 335-359.

11. Canvin JMG, Goutcher SC, Hagig M, Gemmell CG, Sturrock RD. (1997) Persistence of Staphylococcus Aureus as Detected by Polymerase Chain Reaction in the Synovial Fluid of a Patient with Septic Arthritis. Br J Rheumat 36, 203-6.

12. Costerton JW, Geesey GG, Cheng KJ. (1978) How bacteria stick. Scient Am 238, 86-95.

13. Coventry MB (1975) Treatment of infections occuring in total hip surgery. Orthop Clin North Am 6, 991-1003.

14. Dunne WM. (2002) Bacterial adhesion: seen any good biofilms lately? Clin Microbiol Rev 15, 155-66.

15. Fitzgerald RH. (1995) Diagnosis and management of established infections of total hip arthroplasty. J Am Acad Orthop Surg 3, $249-62$.

16. Fitzgerald RH, Randall KR, Brown WJ, Nasser S. (1994) Treatment of infected total hip arthroplasty. Curr Opin Orthop 5, 26-30.

17. Gallo J, Kamínek P, Tichá V, Řiháková P, Ditmar R. (2002) Particle disease. A comprehensive theory of periprosthetic osteolysis: A review. Biomed Papers 2, 21-8.

18. Gambhir A, Kay P, Wroblewski B. (2000) The microbiology of the infected THR. J Bone Jt Surg 83-B, Suppl. I: p. 72.

19. Garvin KL, Fitzgerald RH, Salvati EA, Brause BD, Nercessian OA, Wallrichs SL, Ilstrup DM. (1993) Reconstruction of infected total hip and knee arthroplasty with gentamicin-impregnated Palacos bone cement. Instr Course Lect (AAOS) 42, 293-302.

20. Garvin KL, Hanssen AD. (1995) Infection after total hip arthroplasty. Current Concepts Review. J Bone Jt Surg 77-A: 1576-88.

21. Goldman RT, Scuderi GR, Insall JN. (1996) 2-stage reimplantation for infected total knee replacement. Clin Orthop 331, 118-24.

22. Götz F, Peters G. (2000) Colonization of medical devices by coagulase negative staphylococci. In: Infections associated with indwelling medical devices. Eds. Waldvogel FA, Bisno AL. American Society for Microbiology, 55-88.

23. Gristina AG. (1994) Implant failure and the immuno-incompetent fibro-inflammatory zone. Clin Orthop 298, 106-18.

24. Gristina AG, Hobgood CD, Webb LX, Myrvik QN. (1987) Adhesive colonization of biomaterials and antibiotic resistance. Biomaterials $8,423-36$.
25. Gristina AG, Naylor PT, Webb LX. (1990) Molecular mechanism in musculoskeletal sepsis: The race for the surface. Instr Course Lect 39, 471-86.

26. Gristina AG, Ogam PT, Webb LX, Hobgood CD. (1985) Adherent bacterial colonization in the pathogenesis of osteomyelitis. Science 228, 990-3.

27. Hanssen AD, Osmon DR. (2002) Evaluation of a staging system for infected hip arthroplasty. Clin Orthop 403, 16-22.

28. Hanssen AD, Osmon DR, Nelson CJ. (1996) Prevention of deep periprosthetic joint infection. J Bone Jt Surg 78- $A$, 458-71.

29. Hanssen AD, Rand JA. (1998) Evaluation and treatment of infection at the site of a total hip or knee arthroplasty. JBone Jt Surg 80- $A, 910-22$.

30. Hanssen AD, Osmon DR. (2000) Assessment of patient selection criteria for treatment of the infected hip arthroplasty. Clin Orthop 381, 91-100.

31. Harris WH. (1994) Osteolysis and particle disease in hip replacement. A review. Acta Orthop Scand 65, 113-23.

32. Herrmann M, Vaudaux PE, Pittet D, Auckenthaler R, Lew PD, Perdreau F, Peters G, Waldvogel FA. (1988) Fibronectin, fibrinogen and laminin act as mediators of adherence of clinical staphylococcal isolates to foreign material. J Infect Dis 158, 653-702.

33. Holtom PD, Zamorano D, Patzakis MJ. (2002) Osteomyelitis attributable to vancomycin-resistant enterococci. Clin Orthop 403, 38-44.

34. Holzer G, Windhager R, Kotz R. (1997) One-stage revision surgery for infected megaprostheses. J Bone Jt Surg 79-B, 31-5.

35. Hughes SPF, Anderson FM. (1999) Infection in the operating room. Editorial. J Bone Jt Surg 81-B, 754-5.

36. Cho DR, Shanbhag AS, Hong CY, Baran GR, Goldring SR (2002) The role of adsorbed endotoxin in particle-induced stimulation of cytokine release. J Orthop Res 20, 704-13.

37. Jackson WO, Schmalzried TP. (2000) Limited role of direct exchange arthroplasty in the treatment of infected total hip replacements. Clin Orthop 381, 101-5.

38. Johnston DH, Fairclough JA, Brown EM, Morris R. (1987) Rate of bacterial recolonization of the skin after preparation: Four methods compared. Br J Surg 74, 64.

39. Krickler SJ, Lambert PA. (1992) Extracellular proteins as a potential marker of active Staphylococcus aureus infection in bone. J Med Microbiol 37, 227-31.

40. LaPorte DM, Waldman BJ, Mont MA, Hungerford DS. (1999) Infections associated with dental procedures in total hip arthroplasty. J Bone Jt Surg 81-B, 56-9.

41. Lidwell OM, Elson RA, Lowbury EJ, Whyte W, Blowers R, Stanley SJ, Lowe D. (1987) Ultraclean air and antibiotics for prevention of postoperative infection. A multicenter study of 8, 052 joint replacement operations. Acta Orthop Scand 58, 4-13.

42. Lindquist C, Slätis P. (1985) Dental bacteremia - a neglected cause of arthroplasty infections? Acta Orthop Scand 56, 506-8.

43. Lowy FD. (1998) Staphylococcus aureus infections. N Engl J Med 339, 520-32

44. Lucht U. (2000) The Danish Hip Arthroplasty Register. Acta Orthop Scand 71, 433-9.

45. Mack D, Fischer W, Krokotsch A, Leopold K, Hartmann R, Egge H, Laufs R. (1996) The intercellular adhesin involved in biofilm accumulation of Staphylococcus epidermidis is linear beta-1, 6-linked glucosaminoglycan: purification and structural analysis. J Bacteriol 178, 175-83.

46. Malchau H, Herberts P, Söderman P, Odén A. (2000) Prognosis of total hip replacement. Update and validation of results from the Swedish national hip arthroplasty registry 1979-1998. Scientific exhibition presented at the 67th Annual Meeting of the AAOS, March 15-19, 2000, Orlando, USA.

47. McPherson EJ, Tontz W, Patzakis M, Woodsome C, Holtom P, Norris L, Shufelt C. (1999) Outcome of infected total knee utilizing a staging system for prosthetic joint infection. Am J Orthop 28, $161-5$.

48. Mont MA, Waldman BJ, Hungerford DS. (2000) Evaluation of preoperative cultures before second-stage reimplantation of a total knee prosthesis complicated by infection. A comparison-group study. J Bone Jt Surg 82A, 1552-7.

49. Montanaro L, Arciola CR, Borsetti E, Collamati S, Baldassarri L, Montanaro L. (1999) Detection of fibronectin-binding protein 
genes in staphylococcal strains from peri-prosthesis infections. New Microbiol 4, 331-6.

50. Moussa FW, Anglen JO, Gehrke JC, Christensen G, Simpson WA. (1997) The significance of positive cultures from orthopaedic fixation devices in the absence of clinical infection. Am J Orthop 26, 617-20.

51. Nguyen LL, Nelson CL, Saccente M, Smeltzer MS, Wassel DL, McLaren SG. (2002) Detecting bacterial colonization of implanted orthopaedic devices by ultrasonification. Clin Orthop 403, 29-37.

52. Pagnano MW, Trousdale RT, Hanssen AD. (1997) Outcome after reinfection following reimplantation hip arthroplasty. Clin Orthop 338, 192-204.

53. Pascual A, Fleer A, Westerdaal NAC, Berghuis M, Verhoef J. (1988) Surface hydrophobicity and opsonic requirements of coagulase negative staphylococci in suspension and adhering to a polymer substratum. Eur J Clin Microbiol 7, 161-6.

54. Pascual A, Fleer A, Westerdaal NAC, Verhoef J. (1986) Modulation of adherence of coagulase-negative staphylococci to Teflon catheters in vitro. Eur J Clin Microbiol 5, 518-22.

55. Petty W. (1978) The effect of methylmethacrylate on bacterial phagocytosis and killing by human polymorphonuclear leukocytes. J Bone Jt Surg 60- $A$, 752-7.

56. Petty W, Spanier S, Shuster JJ, Silverthorne C. (1985) The influence of skeletal implants on incidence of infection. Experiments in a canine model. J Bone Jt Surg 67- $A, 1236-44$.

57. Pilnáček J, Bébrová E. (2001) Deep sepsis of THA or TKA Diagnosis and therapy. II. orthopaedic regional symposium, October, 19-20, 2001, Harrachov, Czech Republic.

58. Puolakka TJS, Pajamäki KJJ, Halonen PJ, Pulkkinen PO, Paavolainen P, Nevalainen JK. (2001) The Finnish Arthroplasty register. Report of the hip register. Acta Orthop Scand 72, 433-41.

59. Raad I, Alrahwan A, Rolston K. (1998) Staphylococcus epidermidis: Emerging resistance and need for alternative agents. Clin Infect Dis 26, 1182-7.

60. Raad I, Darouiche R. (1996) Catheter-related septicemia: risk reduction. Infect Med 13, 807-23.

61. Rafiq M, Worthington T, Tebbs SE, Treacy RBC, Dias R, Lambert PA, Elliott TS. (2000) Serological detection of Gram-positive bacterial infection around prostheses. J Bone Jt Surg 82-B, 1156-61.

62. Rand JA, Bryan RS. (1983) Reimplantation for the salvage of an infected total knee arthroplasty. J Bone Jt Surg 65- $A$, 1081-6.

63. Rand JA, Bryan RS, Morrey BF, Westholm F. (1986) Management of infected total knee arthroplasty. Clin Orthop 205, 75-85.

64. Ritter MA. (1999) Operating room environment. Clin Orthop 369 103-9.

65. Sculco TP. (1993) The economic impact of infected total joint arthroplasty. Instr Course Lect (AAOS) 42, 349-51.

66. Segawa H, Tsukayama DT, Kyle RF, Becker DA, Gustilo RB. (1999) Infection after total knee arthroplasty. A retrospective study of the treatment of eighty-one infections. J Bone Jt Surg 81- $A$, 1334-45.

67. Sheretz RJ. (1997) Pathogenesis of vascular catheter-related infections. In: Catheter-related infections. Eds. Seifer H, Jansen B, Farr BM. New York, Marcel Dekker, 1-30.
68. Shlaes DM, Binczewski B. (1990) Enterococcal resistance to vancomycin and related cyclic glycopeptide antibiotics. Eur Clin Microbiol Infect Dis 9, 106-10.

69. Schmalzried TP, Amstutz HC, Au MK, Dorey FJ. (1992) Etiology of deep sepsis in total hip arthroplasty. The significance of hematogenous and recurrent infections. Clin Orthop 280, 200-7.

70. Southwood RT, Rice JL, McDonald PJ, Hakendorf PH, Rozenbilds MA. (1985) Infection in experimental hip arthroplasties. J Bone Jt Surg 67-B, 229-31.

71. Spangehl MJ, Younger ASE, Masri BA, Duncan CP. (1997) Diagnosis of infection following total hip arthroplasty. J Bone Jt Surg 79- $A, 1578-88$.

72. Stout RD, Ferguson KP, Li YN, Lambe DW. (1992) Staphylococcal exopolysaccharides inhibit lymphocyte proliferative responses by activation of monocyte prostaglandin production. Infect Immunol $60,922-7$.

73. Taylor R, Maryan C, Verran J. (1998) Retention of oral microorganisms on cobalt chromium alloy and dental acrylic resin with different surface finishes. J Prosthet Dent 80, 592-7.

74. Tsukayama DT, Estrada R, Gustilo RB. (1996) Infection after total hip arthroplasty. A study of the treatment of one hundred and six infections. J Bone Jt Surg 78- $A$, 512-523.

75. Tunney MM, Patrick S, Gorman SP, Nixon JR, Anderson N, Davis RI, Hanna D, Ramage G. (1998) Improved detection of infection in hip replacements. A currently underestimated problem. J Bone Jt Surg 80-B, 568-72.

76. Ure KJ, Amstutz HC, Nasser S, Schmalzried TP. (1998) Directexchange arthroplasty for the treatment of infection after total hip replacement. An average ten-year followup. J Bone Jt Surg 80- $A$, 961-8.

77. Van Loosdrecht MCM, Lyklema J, Norde W, Zehnder AJB. (1990) Influences of interface on microbial activity. Microbiol Rev 54 , 75-87.

78. Vaudaux P, Francois P, Lew DP, Waldvogel FA. (2000) Host factors predisposing to and influencing therapy of foreign body infections. In: Infections associated with indwelling medical devices. Eds. Waldvogel FA, Bisno AL American Society for Microbiology, 1-26.

79. Waldvogel FA (2000) Staphylococcus aureus. In: Mandell, Douglas and Bennett's principles and practice of infectious diseases. Eds. Mandell GL, Bennett JE, Dolin R. $5^{\text {th }}$ ed. Churchill Livingstone, 2069-92.

80. Whiteside LA (1994) Treatment of infected total knee arthroplasty. Clin Orthop 299, 169-72.

81. Willert HG, Buchhorn GH. (1999) The biology of the loosening of the hip implants. Europ Instr Course Lect 4, 58-82.

82. Younger ASE, Duncan CP, Masri BA. (1998) Treatment of infection associated with segmental bone loss in the proximal part of the femur in two-stages with use of an antibiotic-loaded interval prosthesis. J Bone Jt Surg 80- $A$, 60-9.

83. Younger ASE, Masri BA, Duncan CP, McGraw RW. (1997) The outcome of two-stage arthroplasty using a custom-made interval spacer to treat the infected hip. J Arthroplasty 12, 615-23. 